To cite this article: Jennifer B. Cabaron (2021). FINANCIAL PERFORMANCE OF RURAL BANKS IN THE PHILIPPINES: APPLICATION OF CAMELS MODEL, International Journal of Research in Commerce and Management Studies (IJRCMS) 3 (6): 123-134

\title{
FINANCIAL PERFORMANCE OF RURAL BANKS IN THE PHILIPPINES: APPLICATION OF CAMELS MODEL
}

\author{
Jennifer B. Cabaron \\ College of Business and Accountancy \\ Jose Rizal Memorial State University, Philippines \\ DOI: http://dx.doi.org/10.38193/IJRCMS.2021.3608
}

\begin{abstract}
This study evaluated the financial performance of selected rural banks in the Philippines using the CAMELS model, namely: Capital Adequacy, Asset Quality, Management Efficiency, Earnings Capability, Liquidity, and Sensitivity to Market Risks. The study utilized secondary data of eighty (80) rural banks retrieved from the Bangko Sentral ng Pilipinas (BSP) website. Frequency and percentage were applied to answer the problem set of the study. There was a corresponding formula and criteria used to come up with the CAMELS rating. A rating of 5 corresponds to excellent performance, while a rating of 1 considers the poor performance of the rural bank involved. In general, the results of the CAMEL analysis indicate that sampled rural banks have excellent performance in both Capital Adequacy and Management Quality. They have satisfactory performance on Earnings Quality but poor performance in Asset Quality, Liquidity, and Sensitivity to Market Risk. Thus, the researcher concludes that all rural banks under study have provided ongoing competition in achieving their respective objectives as to financial performance.
\end{abstract}

KEYWORDS: CAMELS, financial performance, rural banks

\section{INTRODUCTION}

Financial performance is significant to banks since it opens the bank's management to determine the bank's overall performance (Dufera, 2010, cited in Zyadat, 2017). According to Mohiuddin (2014), the bank is sound financially healthy not only to its depositors but is equally significant for shareholders, employees, and the country's whole economy. Financial ratio analysis, benchmarking, assessing performance against budget, or a combination of these approaches are used to assess banks and other financial organizations (Avkiran, 2011; Rostami, 2015). There is extensive literature addressing banking performance evaluation. The CAMELS framework is a widely-used methodology for bank performance assessment. It uses specific financial ratios to reflect different aspects of a bank's performance (Sahajwala and van der Bergh, 2000, cited in Dash, 2017). 
According to Dash and Das (2009), there are many methods employed to analyze banking performance. One of the popular techniques is the CAMELS framework, developed in the early 1970s by federal regulators in the USA. Furthermore, in their study, Dash and Das (2009) analyzed India's banking sector using the CAMELS model. The analysis was performed for a sample of fifty-eight banks operating in India, of which twenty-nine were public sector banks, and twenty-nine were private sector/foreign banks. Results revealed that private/foreign banks fared better than public sector banks on most CAMELS factors in the study period.

The CAMELS rating system is based on evaluating six elements of a financial institution's operations: Capital adequacy, Asset quality, Management soundness, Earnings and profitability, Liquidity, and Sensitivity to market risk (Dash and Das, 2009; Reddy and Prasad, 2011). According to Sarker (2005) cited in Aspal, and Dhawan (2016), to examine a bank's performance using the CAMELS rating model, information is obtained from financial statements, funding sources, macroeconomic information, budget, and cash flow projection, and business operations. This model assesses the overall financial position and performance of the bank.

According to the financial management theory, the financial statement analysis is a process of assessing the relationship of the financial statement's components to understand better its performance and position (Khan and Jane, 2007; Ab-Rahim, Kadri, Ee-Ling, and Dee, 2018). This theory has been applied in various domains. This adds to the body of knowledge as an underpinning theory for evaluating the financial performance of rural banks using the CAMELS model.

To the researcher's knowledge, there were only a few studies conducted in the Philippines, specifically, rural banks. Most of them focus on commercial banks in foreign countries. And this study differs from previous researchers by studying the financial performance of rural banks in the Philippines using the CAMELS parameter.

\section{LITERATURE REVIEW}

The CAMELS rating system is based on evaluating six elements of a financial institution's operations: Capital adequacy, Asset quality, Management soundness, Earnings and profitability, Liquidity, and Sensitivity to market risk (Dash and Das, 2009; Reddy and Prasad, 2011). According to Sarker (2005) cited in Aspal, and Dhawan (2016), to examine a bank's performance using the CAMELS rating model, information is obtained from financial statements, funding sources, macroeconomic information, budget, and cash flow projection, and business operations. This model assesses the overall financial position and performance of the bank.

It is necessary to prepare the financial reports, which usually consist of a balance sheet or statement 
of financial position, income statement or statement of financial performance, and cash flow statement to assess the bank (Salhuteru and Wattimena, 2015; Rostami, 2015). The different components of the CAMELS rating model in the form of financial ratios are described below:

\section{CAMELS MODEL}

\subsection{Capital adequacy}

Capital Adequacy is a measure of how banks adequately capitalize on absorbing any losses and meeting customer obligations. Two measures of capital adequacy considered in this study are (i) Capital Adequacy Ratio; and (ii) Debt to Equity Ratio (Rawlin, Mounika, and Shanmugam, 2017). The formula in computing capital adequacy ratio is computed by dividing the sum of Tier 1 capital and Tier 2 capital by the risk-weighted assets (RWA). A higher capital adequacy ratio implies that the bank is well-capitalized relative to its level of risk, hence confirming the banks' long-term solvency (Kasman et al., 2010; and Mimouni, Smaoui, Temimi, and Al-Azzam, 2019).

According to Espenilla (2007), rural banks are expected to satisfy a minimum risk-based capital adequacy ratio of 10 percent. This risk-based capital requirement substantially conforms to the Basel Committee's 1988 Capital Accord and its recent revisions, including the most recent Basel II recommendations.

\subsection{Asset Quality}

Asset quality is one of the essential areas in determining the overall condition of a bank. The main factor affecting overall asset quality is the credit portfolio quality and the credit administration program ("FDIC: Federal Deposit Insurance Corporation," 2020).

The ratio of Gross Non-Performing Loans (GNPL) to Gross Advances (GA) is one of the criteria to evaluate the effectiveness of bankers' credit decisions. Gunsel, (2005); Nimalathasan, (2008); Peterson, (2006); Sarker, (2005) cited in Rostami (2015), as loans have the highest default risk, an increasing number of nonperforming loans shows a deterioration of asset quality.

Ab-Rahim, Kadri, Ee-Ling, and Dee (2018) state that banks with high provision for loan loss ratios indicate that they are taking a higher level of risks. 40 The quality of assets is an important parameter to gauge the strength of a bank. The prime motive behind measuring the asset's condition is to ascertain the component of nonperforming assets as a percentage of the total assets (Reddy and Prasad, 2011). The high rating of Asset Quality shows that banks are good at detecting, measuring, monitoring, and regulating credit risk (Christopulous, Mylonakis, and Diktapanidis 2011; Rozzani and Rahman, 2013). The result of asset quality computations reflects the existing and potential credit risk associated with 
the loan and investment portfolios and off-balance-sheet transactions (FDIC, 2015; Cabaron, Torres, and Cabaron, 2018).

\subsection{Management Efficiency}

Management efficiency signifies adherence to prescribed norms to counter the changing environment, leadership, and administrative capability (Aspal and Dhawan, 2016). It is another essential component of the CAMELS model that guarantees the growth and survival of a bank. According to Dash (2017), management soundness is the parameter used to evaluate management quality, assigning a premium to better-managed banks and discounting poorly-managed banks. High ratings displayed the healthy growth of banks and the high competency of employees that would help the bank grow in the future (Majithiya and Pattani (2010) cited by Rozzani and Rahman, 2013).

\subsection{Earnings Capability}

Strong earnings are essential to the sustainability of banking institutions. Profitability ratios measure a company's ability to generate profits from revenue and assets (Dang, 2011). The quality of earnings in a bank is an extremely significant parameter that expresses the profitability and capability to sustain quality and profits (Aspal and Dhawan, 2016).

For Rahman and Islam (2018), earning quality is a fundamental criterion for evaluating a bank's profitability and performance. It enables the bank to sustain unwanted shocks arising from the bank's risks in its operations. For Samuel (2018), banks depend on their strong earnings capability for performing the activities like funding dividends, maintaining adequate capital levels, providing investment opportunities for the bank to grow, strategies for engaging in new businesses, and maintaining a competitive outlook.

\subsection{Liquidity}

Liquidity is the bank's ability to convert assets into cash. It also denotes the fund available with the bank to meet its credit demand and cash flow requirements 42 (Aspal and Dhawan, 2016). The banks' inability to manage their short-term liquidity liabilities and loan commitment can adversely impact their performance by substantially increasing their cost of funds and overexposure to the unrated asset category (Samuel, 2018).

Moreover, the bank's inability to meet its short-term liquidity requirements can severely impact its profitability and overall performance. A high liquidity ratio indicates that the bank is more affluent to hedge against liquidity risk under stable conditions (Rahman and Islam, 2018). 


\subsection{Sensitivity to Market Risks}

Banks assess the market risk's sensitivity through changes in interest rate, foreign exchange rates, and equity prices. The changes in these variables affect the bank's earning ability (Aspal and Dhawan, 2016). Dash (2017) considers a bank's ability to identify, measure, monitor, and control market risk. Further, according to Gunsel (2005), Nimalathasan (2008), Peterson (2006), Sarker (2005), cited in Rostami (2015), sensitivity ratios are those that are related to risk and the covering power of the organization. It is defined and calculated to finalize the bank's performance model because risk indicators are significant and highlighted in the CAMELS model.

This study was adopted based on the literature cited above and the most common variables for rural banks' financial performance in the Philippines. Thus, the results of this study add to the existing literature in financial performance using the CAMELS model.

\section{MATERIALS AND METHODS}

\subsection{Research design}

This study adopts a descriptive survey method to examine the financial performance of rural banks in the Philippines applying the CAMELS model, namely: Capital adequacy, Asset quality, Management Efficiency, Liquidity, and Sensitivity to Market Risk. These were computed as parameters to evaluate the financial position of the rural banks.

\subsection{Sample and data collection}

In this study, the researcher utilized purposive sampling to select eighty rural banks in the Philippines that published their balance sheet as of March 31, 2019. The names of these rural banks were obtained from the Bangko Sentral ng Pilipinas (BSP) website. The researcher utilized secondary data published on the website of BSP.

\subsection{Data Analysis}

The researcher utilized frequency and percentage to answer the problem set of the study, the rural banks' financial performance based on CAMELS components analysis, frequency, and percentage. The corresponding formula and criteria below were used. A rating of 5 corresponds to excellent performance, while a rating of 1 considers the poor performance of the rural bank involved. 
Table 1. Ratio Classification for Components of CAMELS Rating

\begin{tabular}{|c|c|c|c|c|c|c|}
\hline $\begin{array}{c}\text { Componen } \\
\mathrm{t}\end{array}$ & Ratio & 5 & 4 & 3 & 2 & 1 \\
\hline $\begin{array}{l}\text { Capital } \\
\text { Adequacy }\end{array}$ & $\frac{\text { Equity Capital }}{\text { Total Assets }}$ & $\begin{array}{l}\text { Above } \\
11 \%\end{array}$ & $8 \%-11 \%$ & $4 \%-8 \%$ & $\begin{array}{l}1 \%- \\
4 \%\end{array}$ & $\begin{array}{c}\text { Below } \\
1 \%\end{array}$ \\
\hline $\begin{array}{l}\text { Asset } \\
\text { Ability }\end{array}$ & $\frac{\text { Non-Performing Loans }}{\text { Total Loans }}$ & $\begin{array}{l}\text { Below } \\
1.5 \%\end{array}$ & $\begin{array}{l}1.5 \%- \\
3.5 \%\end{array}$ & $\begin{array}{c}3.5 \%- \\
7 \%\end{array}$ & $\begin{array}{l}7 \%- \\
9.5 \%\end{array}$ & $\begin{array}{c}\text { Above } \\
9.5 \%\end{array}$ \\
\hline $\begin{array}{l}\text { Manageme } \\
\text { nt } \\
\text { Efficiency }\end{array}$ & $\frac{\text { Total Advances (Loans }}{\underline{\text { Receivable) }}}$ & $\begin{array}{l}\text { Above } \\
10-15 \%\end{array}$ & $6 \%-9 \%$ & $3-5 \%$ & $\begin{array}{l}1 \%- \\
3 \%\end{array}$ & $\begin{array}{c}\text { Below } \\
1 \%\end{array}$ \\
\hline $\begin{array}{l}\text { Earnings } \\
\text { Capability }\end{array}$ & $\frac{\text { Net Income (CRE-PRE) }}{\text { Total Assets }}$ & $\begin{array}{l}\text { Above } \\
1.50 \%\end{array}$ & $\begin{array}{l}1.25 \%- \\
1.50 \%\end{array}$ & $\begin{array}{c}1.01 \% \\
- \\
1.25 \%\end{array}$ & $\begin{array}{c}0.75 \% \\
- \\
1.00 \%\end{array}$ & $\begin{array}{l}\text { Below } \\
0.75 \%\end{array}$ \\
\hline Liquidity & $\begin{array}{l}\text { Det Loans } \\
\begin{array}{c}\text { Neposit and Short Term } \\
\text { Funding }\end{array}\end{array}$ & $\begin{array}{l}\text { Below } \\
60 \%\end{array}$ & $\begin{array}{l}60 \%- \\
65 \%\end{array}$ & $\begin{array}{l}65 \%- \\
70 \%\end{array}$ & $\begin{array}{l}70 \%- \\
80 \%\end{array}$ & $\begin{array}{l}\text { Above } \\
80 \%\end{array}$ \\
\hline $\begin{array}{l}\text { Sensitivity } \\
\text { to Market } \\
\text { Risks }\end{array}$ & $\begin{array}{c}\text { Current Assets-Current } \\
\text { Liabilities } \\
\text { Total Capital }\end{array}$ & $\begin{array}{l}\text { Above } \\
80 \%\end{array}$ & $\begin{array}{l}70 \%- \\
80 \%\end{array}$ & $\begin{array}{l}65 \%- \\
70 \%\end{array}$ & $\begin{array}{l}60 \%- \\
65 \%\end{array}$ & $\begin{array}{l}\text { Below } \\
60 \%\end{array}$ \\
\hline
\end{tabular}

Source: Majithiya \& Pattani (2010); Babar \& Zeb (2011); Sarwar \& Asif (2011); Masngut \& Abdul Rahman (2012); Rozzani, \& Rahman, (2013)

\section{RESULTS AND DISCUSSION}

For this research, the balance sheet of selected rural banks as of March 2019 has been utilized to compute financial performance in terms of Capital Adequacy, Asset Quality, Management Efficiency, Earnings Capability, Liquidity, and Sensitivity to Market Risks. Table 2 presents the financial performance (CAMELS) of selected rural banks in the Philippines. 
Table 2. Financial Performance of Selected Rural Banks in the Philippines

Classification of the Banks Based on:

\section{CAR}

Poor

Very Good

Excellent

\section{Asset Quality}

Poor

Fair

Good

Very Good

Excellent

\section{Management Quality}

Good

Very Good

Excellent

\section{Earnings Ability}

Poor

Fair

Good

Very Good

Excellent

\section{Liquidity}

Poor

Fair

Good

Very Good

Excellent

Sensitivity to Market Risk

Poor
Frequency

$\%$

1.3

2.5

2

77

96.3

38

47.5

15

18.8

13

16.3

13

16.3

1

1.3

1.3

1.3

97.5

78

41.3

33

7.5

6

7.5

12

15.0

23

28.8

35

43.8

12

15.0

4

5.0

2

2.5

27

33.8

80

100.0

$$
\mathrm{n}=\mathbf{8 0}
$$

Capital Adequacy. Results revealed that 77 rural banks in the sample or ninety-six (96) percent were on an excellent performance. It provides evidence that rural banks in the Philippines maintain above the minimum capital adequacy ratio of 10 percent. This implies that these banks can absorb any losses and can meet the obligation to their respective customers. 
According to Espenilla (2007), rural banks are expected to satisfy a minimum risk-based capital adequacy ratio of 10 percent. This risk-based capital requirement substantially conforms to the Basel Committee's 1988 Capital Accord and its recent revisions, including the most recent Basel II recommendations. Further, Agusman et al. (2008), citing the work of Karels et al. (1989), pointed out that the higher capital adequacy ratios provide a more significant buffer against default and imply less risk.

For Reddy and Prasad (2011), banks with a higher ratio can absorb an operational loss and determine their capacity to meet the losses. These banks with high capital ratios are also considered safer than those with low capital ratios (Dietrich and Wanzenried, 2014; Chou and Buchdadi, 2016).

Asset Quality. Table 2 shows the financial data results related to the Non-Performing Loans to Total Loans. Results revealed that 38 or 47.50 percent of selected rural banks had poor performance with a ratio of above 9.50 percent. However, this participation in rural banks might lead to a high risk of loans because rural bank borrowers could not pay their obligation on time. Thus, the increasing number of non-performing loans results in a deterioration of the asset quality of banks.

This result is consistent with Ab-Rahim, Kadri, Ee-Ling, and Dee (2018) that banks with high provision for loan loss ratios indicate that they are taking a higher level of risks. Chiaramonte and Casu (2017) pointed out that a robust set of bank failure predictors is strong loan growth and excessive short-term market funding. Also, low-quality assets (high levels of non-performing loans), low profitability, and low capitalization are linked to the accumulation of risk. Moreover, Alhassan, Kyereboah-Coleman, and Andoh (2014) found out in their study that the persistence of nonperforming loans and loan growth is the significant determinant of banks' asset quality. For them, a higher ratio indicates lower bank asset quality.

Management Efficiency shows with high ratings displayed the strong growth of banks and the high competency of employees that would help the bank grow in the future (Majithiya and Pattani (2010) cited by Rozzani and Rahman 2013).

Results revealed that 78 or 97.50 percent of rural banks had excellent performance, while $1.30 \%$ good and very good performance. It implies that these 78 sampled rural banks had higher advances to total deposits with a ratio above 10-15\% based on the financial data extracted from the Bangko Sentral ng Pilipinas (BSP) website. It indicates that the rural banks' board of directors and management team can support business activities, especially advances to stakeholders, and control the risk associated with their operations. As evident, they achieved excellent performance on the management quality aspects. 
Earnings Capability reflects the ability of a bank to generate and sustain an unwanted crisis that may face its bank operations (Rahman and Islam. 2018). It shows the financial data results related to the Net Income over the Total Assets of participated in rural banks.

It was found that on the Earnings ability ratio, 23 or $28.80 \%$ rural banks had excellent performance with a ratio of above $1.50 \% ; 12$ or $15 \%$ very good performance (ratio of $1.25 \%-1.50 \%$ ); 6 or $7.50 \%$ fair and good performance (ratio of $0.75 \%-1.0 \%$ ); and 33 or $41.30 \%$ poor performance with a ratio below $0.75 \%$. Almost half of the participated rural banks had performed poorly under the ROA ratio. One participated rural bank had negative earnings as of March 2019. However, 28.80\% of rural banks performed excellently where their profits could fully support long-term banking operations.

Liquidity. It shows the result of Net Loans to Deposit and Short-term Funding of selected rural banks in the Philippines. On the liquidity ratio, 27 or 38.80\% sampled rural banks had excellent performance with a rate below $60 \%$. While $43.80 \%$ participated in rural banks releasing loans above $80 \%$, their liquidity ratio was high due to net loans over the deposit and short-term funding. This high liquidity ratio results in the banks having poor liquidity.

Sensitivity to Market Risk. It shows the result of Current Assets less Current Liabilities to Total Capital. Results revealed that all sampled rural banks had poor performance on Sensitivity to market risk with a ratio below $60 \%$. The poor rating of Sensitivity displayed that the rural banks might not be sensitive in releasing loans to their borrowers. Thus, the loan portfolio can be problematic when considered non-performing loan portfolios, which is caused not to be sensitive to their markets.

\section{CONCLUSION}

The financial performance of rural banks applying the CAMELS parameter has an excellent performance in both Capital Adequacy and Management Quality. They have satisfactory performance on Earnings Quality but poor performance in Asset Quality, Liquidity, and Sensitivity to Market Risk. The rural banks under study have provided ongoing competition in achieving their respective objectives. Further, the rural banks might be sensitive in releasing their loans because this will affect their liquidity. It is recommended that future researchers study the two years of the banks' financial statements.

\section{REFERENCES}

Ab-Rahim, R., Kadri, N., Ee-Ling, A. C., \& Dee, A. A. (2018). CAMEL Analysis on 96-105.

Performance of ASEAN Public Listed Banks. International Business Research, 11(4), 
Vol. 3, No. 06 Nov-Dec; 2021 Page. No. 123-134

Aspal, P. K., \& Dhawan, S. (2016). Camels Rating Model For Evaluating Financial Performance of Banking Sector: A Theoretical Perspective. International Journal of System Modeling and Simulation, 1(3), 10-15.

Avkiran, N. K. (2011). Association of DEA super-efficiency estimates with financial ratios: Investigating the case for Chinese banks. Omega, 39(3), 323-334.

Babar, H. Z., \& Zeb, G. (2011). CAMELS rating system for banking industry in Pakistan: Does CAMELS system provide similar rating as PACRA system in assessing the performance of banks in Pakistan?

Cabaron, J., Torres, B. \& Cabaron, R. (2018). Financial performance of publicly-listed Philippine banks in the ASEAN market. International Journal of Current $\quad$ Research, 10, (09), 73498-73502

Christopoulos, A. G., Mylonakis, J., \& Diktapanidis, P. (2011). Could Lehman Brothers' collapse be anticipated? An examination using CAMELS rating system. International Business Research, 4(2), 11.

Dang, U. (2011). The CAMEL rating system in banking supervision. A case study.

Dash, M. (2017). A model for bank performance measurement integrating multivariate factor structure with multi-criteria PROMETHEE methodology. Asian Journal of Finance $\quad$ \& Accounting, 9(1), 310-332.

Dash, M., \& Das, A. (2009). A CAMELS analysis of the Indian banking industry. Available at SSRN 1666900.

Dufera, A. (2010). Financial performance evaluation: A case study of Awash international bank. Unpublished MSc Project. Mekelle University, Ethiopia.

Espenilla Jr, N. A. (2007, December). Banking Supervision and Examination in the Philippines. In Conference on "Financial Stability and Financial Sector Supervision: Lessons from the Past Decade and Way Forward," Organized by IMF- Regional Office for Asia and the Pacific, Keio University and Japan Financial Services Agency.

Gunsel, N. (2005). Financial ratios and the probabilistic prediction of bank failure in North Cyprus. Editorial Advisory Board e, 18(2), 191-200.

Majithiya, R., \& Pattani, A. (2010). Rating the performance of the bank through CAMELS model. Post Diploma thesis, Tolani Institute of Management Studies,

India. 
Vol. 3, No. 06 Nov-Dec; 2021 Page. No. 123-134

Masngut, M., \& Abdul Rahman, R. (2012, December). Financial distressed: detection model for Islamic banks. In Business and Social Science Research Conference.

Mimouni, K., Smaoui, H., \& Temimi, A. (2019). The impact of Sukuk on the performance of conventional and Islamic banks. Pacific-Basin Finance Journal.

Mohiuddin, G. (2014). "Use of CAMEL Model: A Study on Financial Performance of Selected Commercial Banks in Bangladesh", Universal Journal of Accounting and Finance, 2(5), 151-160.

Nimalathasan, B. (2008). A comparative study of financial performance of banking sector in Bangladesh. An application of CAMELS rating system. Universitatii Bucuresti. Analele. Seria Stiinte Economice si Administrative, 2, 133.

Rahman, M. Z., \& Islam, M. S. (2018). Use of CAMEL Rating Framework: A Comparative Performance Evaluation of Selected Bangladeshi Private Commercial Banks. International Journal of Economics and Finance, 10(1), 120-128.

Rawlin, R., Mounika, M., \& Shanmugam, R. (2017). Comparative analysis of top private sector banks in India based on CAMEL parameters. MUDRA: Journal of Finance and Accounting, 4(1), 58-69.

Reddy, D. M., \& Prasad, K. V. N. (2011). Evaluating performance of regional rural banks: an application of CAMEL model. Researchers World, 2(4), 61.

Rostami, M. (2015). CAMELS Analysis in Banking Industry. Global Journal of Engineering Science and Research Management, 2(11), 10-26.

Rozzani, N., \& Rahman, R. A. (2013). Camels and performance evaluation of banks in Malaysia: conventional versus Islamic. Journal of Islamic Finance and Business $\quad$ Research, 2(1), 36-45.

Sahajwala, R., \& Van Den Bergh, P. (2000). Supervisory risk assessment and early warning system. Basel Committee on Banking Supervision Working Papers.

Salhuteru, F., \& Wattimena, F. (2015). Bank performance with CAMELS ratios towards earnings management practices in state banks and private banks. Advances in Social Sciences Research Journal, 2(3), 301-314.

Samuel, E. M. (2018). Comparative Performance Evaluation of Selected Commercial Banks in India using CAMELS Rating Model. International Journal of Global $\quad$ Sustainability, 2(1), 2438.

Sarker, A. (2005). CAMELS rating system in the context of Islamic banking: A proposed 'S'for 
Shariah framework. Journal of Islamic Economics and Finance, 1(1), 78-84.

Sarwar, A., \& Asif, S. (2011). Safety \& soundness of financial sector of Pakistan: CAMEL rating application. Interdisciplinary Journal of Contemporary Research in Business, 3(2), 624630.

Zyadat, A. A. H. (2017). The impact of sustainability on the financial performance of Jordanian Islamic banks. International Journal of Economics and Finance, 9(1), 55-63. 